\title{
North American Multi-Purpose Dear Introducent Plants in Western Georgia Humid Subtropical Conditions
}

\author{
Mariam Metreveli ${ }^{1,2}$, Avtandil Meskhidze ${ }^{1}$, Feride Tchaidze ${ }^{2}$, Julieta Jakeli ${ }^{2}$, Dali Beridze ${ }^{1}$ \\ ${ }^{1}$ Batumi Shota Rustaveli State University, Biology Department, Faculty of Natural Sciences and Health Care, Batumi, Georgia \\ ${ }^{2}$ Batumi Botanical Garden, Batumi, Georgia
}

Email address:

metrevelim@list.ru (M. Metreveli), meskhidze.a@gmail.com (A. Meskhidze), feride_tchaidze@mail.ru (F. Tchaidze), juli.jakeli@mail.ru (J. Jakeli), dalidali59@gmail.com (D. Beridze)

\section{To cite this article:}

Mariam Metreveli, Avtandil Meskhidze, Feride Tchaidze, Julieta Jakeli, Dali Beridze. North American Multi-Purpose Dear Introducent Plants in Western Georgia Humid Subtropical Conditions. American Journal of Environmental Protection. Special Issue: Applied Ecology: Problems, Innovations. Vol. 4, No. 3-1, 2015, pp. 168-174. doi: 10.11648/j.ajep.s.2015040301.36

\begin{abstract}
The article deals with bioecological peculiarities and application of exotic plants Liquidambar styraciflua L., Liriodendron tulipifera L. and Magnolia grandiflora L. introduced in Adjara or the South Colchis Black Sea littoral in the conditions of Transcaucasia, namely, Western Georgia humid subtropics. Namely, the following has been studied peculiarities of growth and development, adaptation, reproduction and natural rehabilitation, Antimicrobial Action of Extracts Obtained from Leaves. The multifold application recommendations are given on.
\end{abstract}

Keywords: South Colchis, Exotic Plants, Bioecological Peculiarities, Adaptation, Antimicrobial Action

\section{Introduction}

We have set as our aim to study some bioecological peculiarities of North American exotic plants Liquidambar styraciflua, Liriodendron tulipifera and Magnolia grandiflora introduced in Adjara Black Sea littoral in the conditions of Western Georgia humid subtropics.

The Black Sea littoral of Georgia is distinguished by the diversity of the local as well as exotic, introduced flora. Especially interesting in this respect is the Ajara, namely, Batumi coastline [1, 2, 3]. Adjara or South Colchis floristic region occupies one of the significant places in the Caucasus by vegetation diversity, high specific share of endemism and uniqueness of forest ecosystems. With historical past of vegetation, the specific composition of floristic complexes, systematic structure the territory of Adjara belongs to Colchis or East Euxeinos province of the sub-Mediterranean region of the Mediterranean world. Its floristic diversity is characterized by the flora of the tertiary period Mediterranean autochthonic origin [4, 5]. At present Ajara is mentioned as Southern Kolkheti (Colchis).

At the same time, it is remarkable that the introduction of plants began here as early as the end of the 19th century and today, many of them have been implemented into decorative gardening, subtropical agriculture and other fields of economy. The origins of distribution and implementation of exotic plants in practice take place from the Batumi Botanic Garden that is included in the unique botanic gardens worldwide. It is century old and is arranged according to the principle of phyto-geographical sections. The Garden represents over 2000 woody plant species characteristic to all the continents of the world, including North American moody introduce the number of which reaches 217 species for today. A number of scholarly works have been dedicated to the study of the adaptation of exotic plants along the Georgian Black Sea littoral $[6,7,8,9,10]$.

The nature of Georgia is quite diverse and each of its regions is characterized by specific soil-climatic conditions. Diversity of Georgian climate is preconditioned, on the one hand, by its location at the northern border of subtropical zone between the Caspian and Black Seas, and on the other hand, by the particular complexity of its relief - Caucasus ranges of various heights and directions. Atmospheric processes developed with moderate as well as subtropical zones participate in the formation of climate in Georgia. Adjara is situated in the southwestern part of Georgia and is distinguished by specific physical-geographical peculiarities that are determined by a number of reasons. Significant among them is the location of Adjara in southern latitudes that stipulates abundance of solar energy, and the climatic impact of the Black Sea that is more revealing along the 
coastline. It is along the coastline that Liquidambar styraciflua, Liriodendron tulipifera and Magnolia grandiflora grow, within the height of $0-250$ meters. These areas are distinguished by subtropical climatic conditions, directly border the sea and are protected by the mountains from three sides. The thermal regime is preconditioned by the geographical locations, the direct closeness to the sea. The average annual air temperature in $14-150^{\circ} \mathrm{C}$; the average temperature of the coldest month January is $6-70^{\circ} \mathrm{C}$; the temperature of the warmest months - July and August - is $220^{\circ} \mathrm{C}$. The lowest temperatures are -8 and $-90 \mathrm{C}$. The highest temperature is $360^{\circ} \mathrm{C}$. The average quantity of annual precipitation is $2500 \mathrm{~mm}$, whereas general $-2500-3500 \mathrm{~mm}$. The relative air humidity is $80-82 \%$. There are mostly red soils. It rarely snows, but when it does, it sometimes reaches $1 \mathrm{~m}$ and because of wetness it in most cases destructively affects some of the exotic plants [9, 11].

The natural habitats of our exotics are the mixed-type forests of the central, eastern, southern and southeastern states of eastern USA where the climate is mostly of the Atlantic-monsoon type of moderate and subtropical zone [12, $13,14]$.

We have studied the growth, development, reproduction and natural rehabilitation peculiarities of Liquidambar styraciflua, Liriodendron tulipifera and Magnolia grandiflora, as well as defined their frost-resistance and winter-resistance qualities. For the purpose of defining their role in environmental improvement, we have studied the antimicrobial action on the example of protistocidal activity. An experiment is started for the determination of bactericidal and fungicidal actions of extracts obtained from the leaves. As it is well known, plants can produce biologically active substances of complex chemical composition that represent one of the preconditioning factors of plant immunity; they have antimicrobial activity and destroy or prevent development of pathogenic microorganisms and simple unicellular organisms (sometimes, multi-cellular organisms too). These biologically active substances are known as phytoncides $[15,16]$. Volatile phytogenic compounds conduct health-improvement effect of the environment - they are one of the important regulators of air physical-chemical composition. Application of antimicrobial action of plant phytoncides or "natural antibiotics" is available in ecology, medicine, agriculture and other fields. As far as the species under study represent important garden and park plants with a grand crown and leaves, we got interested in antimicrobial activities of extracts obtained from their leaves.

\section{Materials and Methods}

For the determination of the growth and development peculiarities of the North American exotic plants Liquidambar styraciflua, Liriodendron tulipifera and Magnolia grandiflora along the Adjara coastline of the Georgian Black Sea littoral applying corresponding methodology, we have studied the growth, leaf-bearing, flowering, fruit development, seed production and dissemination processes of the solid age specimens growing in the Batumi Botanical Garden. Each decade of every month during the whole year we were observing the phases of bud swelling and opening, complete leaf-bearing and leaf-falling, sprout growth beginning and ending, generative buds swelling and flowering starts and ending, fruit knotting, development and seed dissemination. For the determination of the adaptation degree of the exotics we have fixed the degree of their natural rehabilitation in new environments, namely, the degree of self-regeneration through seeds and vegetation $[17,18]$; we have also studied the impact of one of the limiting factors for exotics' adaptation along the Ajara coastline of the Georgian Black Sea littoral - periodical low temperatures and the thickness of snow [19]; as far as all the three exotic plants are the rare species for the organization of parks and forests and their role is interesting in environment improvement, we have studied the antimicrobial action of their leaf extract. We have obtained the final results of prosticidal action on the basis of several repeated experiments. In the case of determination of prosticidal action, the simple unicellular organism - Paramecium caudatum - was used. The experiment was based on the Boris Tokin method $[15,16]$ according to which prosticidal action is determined by the time of complete destruction of infusorians under the action of leaf extract. The degree of bactericidal and fungicidal activity is in the process of study, for which we use the strains of fungus and bacterial pathogenic cultures, including quarantine pathogens, existing at the Institute of Phytopthology and Biodiversity of Batumi Shota Rustaveli State University. For the comparative analysis, we have included in the experiment the worldwide acknowledged plant species of strong antiseptic action: onion (Allium cepa L.), garlic (Allium sativum.), myrtle (Myrtus communis l.), geranium (Pelargonium roseum Ait.); we have studied the peculiarities of graft and seed reproduction with control and bio-stimulator variants at the Batumi Botanical Garden orangery and nursery $[20,21]$.

\section{Results and Discussions}

\subsection{Growth, Reproduction and Adaptation Peculi-arities}

\subsubsection{Growth and Development Peculiarities}

Below are given the results of several years' observations on the growth phases of the exotics under study. The process of each phase is given in calendar dates (table 1).

Liquidambar styraciflua L. - Family Altingiaceae Lindl. [22].

They are high deciduous trees, with straight, elegant stem and broad pyramid-shape crown. Centenary trees in Adjara are usually 30-35 $\mathrm{m}$ high with stem diameter of 1-1,5 m. Massive swelling of vegetative buds begins in late February early March; buds open from second-third decade of March; apical growth starts in the third decade of March and lasts till July in most cases, but sometimes ends at the end of June or lasts till first decade of August inclusive. The average growth comprises $8,5 \mathrm{~cm}-20,5 \mathrm{~cm}$. On shoots some callus-like growths can develop. Leafing stage begins in late March early April. Leaf color changes from the first decade in 
November, leaf falling begins from the second decade in November and continuing till the third decade in December. The average size of 5-7 lobed leaves is $15-20 \mathrm{~cm}$. The plant massively flowers from the third decade in March to the first decade of May during which period the plant is beautified by masculine inflorescence in the form of long apical brushy bunches and single hanging glomes. Fruit ripening starts from the third decade of October and ends in November. Dissemination from the spherical long-stem hanging collective fruit made up of numerous small boxes ends by the third decade of December. Diameter of ball-shape collective fruits is $2,5-4 \mathrm{~cm}$. There are very small $1-2$ seeds in each small box. Empty fruits remain on the trees till spring. Fruit-bearing is abundant.

The comparison of flowering and fruit-bearing dates in the habitat is given in the table 2 .

It should be noted that along our coastline the dates of vegetative and generative development of North American and East Asian liquid ambars coincide, i.e. they begin development from March and continue till the third decade of November total comprising 8-9 months. They flower in March-April and give fruit in October-November-December. They are characterized by vegetative and mixed-type bud development. When in spring the mixed-type bud open, first the flowering process takes place, followed afterwards by leafing and apical growth processes.

Liquidambar styraciflua $L$. is considered to be one of the most beautiful decorative plants inasmuch as it is effective due to beautiful, symmetrical, wide, pyramid-shed crown and changing leaf colors, especially in autumn when it is colored with orange, red and purple leaves and very beautiful, hanging, spherical, round cone-like fruit. Liquidambar resinous or amber tree is also interesting for the purpose of using its walnut-like texture wood and composition of aromatic "ambra liquida" balsamic compounds in medicine and perfumery[23].

Liquidambar styraciflua $L$. is a species protected by IUCN Red List and is the category of LC (Least Concern)[24,25,26].

Liriodendron tulipifera L.-Family Magnoliaceae Juss.

It is a huge, tall deciduous tree-plant, growing about $60 \mathrm{~m}$ high with 3-4 m diameter. It has grown in the territory of the Batumi Botanical Garden since 1913. Centenary specimens reach here $35 \mathrm{~m}$ height, stem diameter $-160 \mathrm{~cm}$, crown projection $-24 \times 20 \mathrm{~m}$. Swelling of vegetative buds begins in March and sprout growing (shooting) - in early April. Sprout growing generally ends at the end of July whereas on the upper branches it continuous till mid August. The average length of the shoots annual growth is $25 \mathrm{~cm}$. Leaves are $4-6-$ lobed. By the end of July the length of the grown leaves reaches up to $15 \mathrm{~cm}$. Leaves become yellow and begin to fall gradually. In the first half of November all the leaves have already obtained beautiful golden-yellow colouring. The massive falling of leaves begins in the second half of November and ends in December. Flowering begins from the second half of April till the end of May, sometimes including the first half of June. Flowers appear on the mixed-type shoots of the current year. These shoots begin growing earlier than the vegetative shoots and end very soon, remaining short, about $5 \mathrm{~cm}$ long. Vegetative buds develop at the top. They soon swell, grow and give first flowers already in the second or third decade of April, in the period of massive leafing of the plant, in conditions of $14-15^{\circ} \mathrm{C}$ temperature. Flowers are single, androgynous, arranged at the top of the shoot, $6 \mathrm{~cm}$ diameter; 6 crown petals are yellow-greenish with an orange-reddish spot at the stem. They resemble tulips in shapes, hence their name. They yield cucumber-like aroma and are melleous. In the eastern part of the USA it is a very mellous plant. Flowering is annual. Respectively, fruit-bearing is annually too, and is quite abundant. Fruit is of $3,5-5 \mathrm{~cm}$ long, cone-like collective fruit directed upwards to short shoots, and consists of a stem and numerous $4 \mathrm{~cm}$ long alates with one wing and four faceted seeds that fall after ripening. Seed ripening begins at the end of October and in November massive ripening proceeds. Ripen "cones" open in single wings that can be spread by wind. By the end of December all the seeds are disseminated already and only the stem remains on the tree where seeds were placed. These stems remain all through winter, sometimes up to the appearance of new leaves.

The comparison of flowering and fruit-bearing dates in the habitat is given in the table 2 .

Like the south-eastern region of the USA, Liriodendron is considered as a marvelous decorative and important garden-park plant along the Ajara Black Sea littoral with the size of its crown, projection, grace, especially colors of autumn leaves and beautiful flowering. It is a valuable mellous plant for bee keeping. It is also well known for its precious wood. Interested farmers cultivate it for this purpose and get desirable results. The roots, bark and leaves can be used for medicinal purposes (especially due to tulipiferine consistency)[23,27].

Magnolia grandiflora L.-Family Magnoliaceae Juss.

Magnolia grandiflora, is an evergreen tall tree. In the habitat it reaches $30 \mathrm{~m}$ height, stem diameter is $1,5 \mathrm{~m}$. In the conditions of Ajara the height of the centenary ones reaches 22-25 $\mathrm{m}$, stem diameter - 1-1, $5 \mathrm{~m}$; the crown is wide-pyramid-shape, is characterized by dense branching, massively fuzzy vegetative buds are produced at the shoot tops and leaf bays. Flower buds are created at the top of the previous year shoots, they are also fuzzy. The leaves are big, leather, whole-edged, shiny, $12-25 \mathrm{~cm}$ long; leaves live $2-2$, 5 years. Two-year old leaves become yellow and fall in spring (April-May), when new leaves appear. During the first intensive period of leaf-falling the $50-60 \%$ fall is observed in two-year leaves. There is massive leaf-falling in May. In summer leaf-fall decreases (15\%), in autumn $40 \%$ of the rest of the 2, 5-year leaves fall. In the hot summer conditions the leaf-falling increases. Young leaves have soft, light green plates. By the early June the leaves become leather and obtain dark-green coloring. Thus, $M$. grandiflora has 2 well-expressed periods of leaf falling - spring and autumn. During the first years of life $M$. grandiflora grows rather slowly by in 10 years time, especially in conditions of fertile soil, it grows very fast and yields annual shoot growth up to 0 , $5-0,6 \mathrm{~m}$.

The growth and development of this magnolia is very 
interesting because of its being an evergreen plant. Vegetation begins significantly late, in April. Simultaneous to this phenophase leaves open and shoot growing starts. The entire leafage conducts $29 / \mathrm{V}-5 / \mathrm{VI}$; new leaves open until 10-15 July when shoot growth finishes. Sometimes shoot growth lasts till July-August and ends in the production of apical bud. Mostly, in August II growth appears that is produced from terminal buds opened in the upper branches. One-year shoots get branched in mid June and produce II stage shoots from accessory vegetative buds that long continue growing and exceed mother shoots 3-4 times. Next year, generative buds and vegetative accessory buds are produced at the apex of short generative shoots. They can open the same year, but the main shoot does not grow any more. Vegetative shoot is long and produces vegetative buds at the apex as well as leaf bosoms. Next year it will be the lateral shoots that continue growth and not the main-parent ones. Shoot growth is 26-35 $\mathrm{cm}$ in average. Shoot wooding begins from 25/VI-10/VII and ends by 20-30 August. The growth and flower buds are quite shaped by the end of July. At the beginning of October all the parts of the flower can be distinguished in the vegetative buds.

Generative buds swell a bit later than vegetative ones. At the beginning of May buds greatly increase in size and begin to develop for 20-35 days, ending in flowering (end of May beginning of June). The diameter of the apical, single milky-white, androgynous flowers arranged in three circles and consisting of 6-9 crown petals, is $25-30 \mathrm{~cm}$. During bad weather conditions small bugs inhabit the flowers by means of which the pollination process is conducted. M. grandiflora flowers do not open all together, but in succession, from May to the end of October. Massively flowering takes place in June-July; afterwards it slows down and then restarts again.
Single flowers can open even in November along the Adjara coastline.

Like vegetation, flowering is a long process. Flowers and ripe seedy fruits can be found in trees simultaneously. Sometimes, in October, on older specimens, you can see together buds, developed buds, flowers, fruits and ripe seeds. $12 \mathrm{~cm}$ long and $6 \mathrm{~cm}$ wide collective fruits are straight-standing "multi-leaves" in the form of big "cones". Fruits are knotted all through the summer, sometimes in autumn too. From fruit knotting up to its ripening 150-160 days pass. Fruit ripens in October-November. There are 20-25 seeds in one cone. Seeds are black, bean-shape, oblong, rather thick, 3-6 $\mathrm{mm}$ in diameter, 6-15 $\mathrm{mm}$ in length, covered with bright red fleshy jacket. The massive fall of the seed takes place after their complete ripening. After seed falling "cones" gradually fade away and fall, but sometimes empty, dry cones will remain in trees until the next year vegetation period. Satisfactory fruiting is developed in well-lighted trees, whereas the badly-lighted ones. In the Adjara coastline conditions the plant bears fruit annually, in most cases massively.

The comparison of flowering and fruit-bearing dates in the habitat is given in the table 2 .

Magnolia grandiflora, is a highly decorative plant for the Adjara littoral. It is a unique garden-park with its elegant crown, leaves similar to Ficus elastic leaves, beautiful flowers, cone-like fruit and red-jacket seeds hung on threads in ripening season, as well as adaptation to city conditions. It is also a very interesting plant in medicine and perfumery for containing essential oils in all the organs and alkaloids, glycosides and essential oils in the leaves [23].

Table 1. Phenological Cycle (by months) of Liquidambar styraciflua, Liriodendron tulipifera, Magnolia grandiflora in the Humid Subtropical Conditions along Adjara Black Sea Littoral.

\begin{tabular}{|c|c|c|c|c|c|c|c|c|c|c|c|}
\hline \multirow{2}{*}{ № } & \multirow{2}{*}{ Species } & \multicolumn{2}{|c|}{ Growth } & \multicolumn{2}{|c|}{ Leafing } & \multicolumn{2}{|c|}{ Flowering } & \multicolumn{2}{|c|}{ Fruiting } & \multicolumn{2}{|c|}{ Leaf falling } \\
\hline & & start & end & start & end & start & end & start & end & start & end \\
\hline 1 & Liquidambar styraciflua & III, IV & VII & IV & $\mathrm{V}$ & III & $\mathrm{V}$ & $\mathrm{X}$ & XI & XI & XII \\
\hline 2 & Liriodendron tulipifera & III, IV & VII & IV & VI & IV & VI & $X$ & $\mathrm{XI}$ & XI & XII \\
\hline 3 & Magnolia grandiflora & IV & VIII & IV & VI & $\mathrm{V}, \mathrm{X}$ & VIII, XI & $\mathrm{X}$ & XI & III, X & V, XII \\
\hline
\end{tabular}

Table 2. Flowering and Fruiting Dates of Liquidambar styraciflua, Liriodendron tulipifera, Magnolia grandiflora in Habitat and along Adjara Black Sea Littoral.

\begin{tabular}{|c|c|c|c|c|c|}
\hline № & Species & Flowering in habitat & Fruiting in habitat & Flowering in Adjara & Fruiting in Adjara \\
\hline 1 & Liquidambar Styraciflua & May & October & March-May & October- November \\
\hline 2 & Liriodendron Tulipifera & April-May (June) & October & April-May (June) & October- November \\
\hline 3 & Magnolia Grandiflora & May-August & October & $\begin{array}{l}\text { May-July/ August; } \\
\text { October-November }\end{array}$ & October- November \\
\hline
\end{tabular}

\subsubsection{Peculiarities of Reproduction and Natural Rehabilitation}

One of the signs of adaptation of the exotic plants to the new environmental conditions is the degree of reproduction and natural rehabilitation with seeds as well as vegetative way.

For the determination of this peculiarity we have conducted collecting and planting of all three types of seeds. Also, taking stem grafts and rooting with using test variants and growth stimulators. As growth stimulators, we have used $0,01 \%$ of indoleacetic acid and 2\% sucrose solutions. For graft rooting we used mixed substrate of peat, sand and humus. Grafting results are shown in the table 3 whereas the seed reproduction results are discussed in the text.

In case of Liquidambar styraciflua, the seed taken in autumn was planted in spring (March) and it gave better results rather than planting right after seed taking. In this 
occasion the developmental degree comprised $40-75 \%$, while the degree of development for the seeds taken in autumn was about $30 \%$. Seeds grow rather slowly; they begin branching from 3-4 years, i.e. this is the time when cork-like sprouts appear. The height of 3-year-old plants is $20-40 \mathrm{~cm}$. According to the sources, liquidambars begin reproductive development rather late, at the age of 10-15 years. However, out of seedlings obtained by us for years, the 6-7-year old specimens gave flowers and even fruits. Graft reproduction of liquidambar stems did not give any results in our experiment.

It should be noted that on the territory of the Batumi Botanical Garden as well as all over the littoral, there are numerous self-seeding forms around the centenary liquidambars.

Out of the seeds obtained from Liriodendron tulipifera fruits, only $5 \%$ appears to be of normal development. Respectively, we received low percent of seed germination in our experiment, and that was only in spring, the first decade of March, and not in autumn. Seedlings obtained from spring sowing grow and develop very well. According to the sources, liriodendrons begin reproductive development rather late, at the age of 20-25 years. However, out of seedlings obtained by us for years, the 10-12-year old specimens gave flowers and even fruits. Summer graft reproduction gave good results. The degree of rooting, increased by $30 \%$ after using bio-stimulators.

On the territory of the Batumi Botanical Garden as well as all over the littoral, there are numerous natural self-seeding and vegetative forms around the centenary liriodendrons. Abundance of self-seeding can be explained by seed development in great numbers. Among them, relatively old-aged specimens produce flowers and fruits.

We have processed the seeds of Magnolia grandiflora well before sowing, that means that, first of all they were rid of red fleshy jackets and washed. Part of the seed is planted right after taking in autumn and it gives $40-45 \%$ of growth. The other part is kept in cold conditions with stratification till spring. The seed stored in damp peat moss and placed in polyethylene sacks are in the refrigerator till spring. Seeds planted after 4-4,5 months of stratification show $30 \%$ of growth. Seedlings are characterized by unusually slow growth: the height of 6-year-old seedlings is $2,5 \mathrm{~cm}$ that gives flowers at this age. Rooting of spring grafts shows very good results and the degree of rooting using bio-stimulators increases to $40-45 \%$.

Centenary exotics of Magnolia grandiflora do not develop self-seeding in the subtropical climatic conditions of Adjara Black Sea littoral. However, there are numerous specimens received after rooting from branches bent to the earth that creates an association to the mangrove forests. I

Table 3. Results of Vegetative Graft Rooting.

\begin{tabular}{|c|c|c|c|c|c|}
\hline \multirow{2}{*}{ № } & \multirow{2}{*}{ Species } & \multirow{2}{*}{ Number of grafts } & \multicolumn{3}{|c|}{ Degree of rooting in \% } \\
\hline & & & Test version & Indoleacetic acid $0,01 \%$ & Saccharin $2 \%$ \\
\hline 1 & Liquidambar tyraciflua & 100 & 0 & 0 & 0 \\
\hline 2 & Liriodendron tulipifera & 100 & 30 & 60 & 65 \\
\hline 3 & Magnolia grandiflora & 100 & 35 & 75 & 80 \\
\hline
\end{tabular}

\subsubsection{Peculiarities of the Adaptation to New Environment}

One of the signs of the complete adaptation of exotic plants to the new environmental conditions is the resistance towards limiting factors. For the Adjara humid subtropical climate such factors are: periodical frosty winter $\left(-8-9^{0} \mathrm{C}\right)$, periodical snow up to $0,5-0,8 \mathrm{~m}$ high and strong wind. According to the works of the local scientists as well as our observations we can conclude that during the century all the three exotics have managed to overcome critical dangers from the above given factors positively. Only sometimes, young sprouts of liriodendrons are characterized by fragility and the plant gets mechanically damaged by heavy snow. IN general, all the three species are characterized by high ability of adaptation. There is one colorful huge specimen of liriodendron at the Batumi Botanical Garden which several years ago got rooted out during the tempest only because it was growing at the edge of the valley. However, it entirely stretched over the valley and created a live bridge, the roots and apical branches were covered with earth and it got successfully rooted again. The tree has still been alive for over 30 years already. Its branches took vertical direction; they grow, produce flowers and fruits and together with specimens received from the apical branches create the association of children trees grown from the tree stretched over the valley.

\subsection{Determination of Antimicrobial Action of Extracts Obtained from Liquidambar Styraciflua, Liriodendron Tulipifera, Magnolia Grandiflora Leaves}

For the purpose of defining antimicrobial activity of the extracts obtained from the leaves of the species under study, we have included in the analysis fungal and bacterial pathogens obtained in pure culture during phytopathological research at the Institute of Phytopathology and Biodiversity. However, we have not finished the experiments yet due to insufficient number of repetitions. They are in the process and we refrain from making any conclusions about the results. At this stage we give the results of protistocide action below.

We determined protistocide action according to the time of the complete destruction of Paramecium caudatum upon the impact of volatile phytoncide compounds of the extract obtained from leaves $[15,16]$. The material for analysis was taken in spring, summer and autumn periods. The extract was obtained by squeezing well-crushed leaves.

Experiments were conducted during 3 years in three calendar dates of different phases of vegetative and generative development: the last decade of May, the first decade of August and the first decade of October. According to the obtained result, we conclude that the activation of phytoncide 
actions increases from spring to summer while afterwards decreases from summer towards autumn. Exotics are characterized by the highest phytoncide activities in August (table 4).

Table 4. Protistocide activity of the species under study.

\begin{tabular}{lllll}
\hline \multirow{2}{*}{ No } & \multirow{2}{*}{ Species } & \multicolumn{2}{l}{ Last decade of May } & \\
\cline { 3 - 5 } & & Exposition time & Necessary time to kill infusories (in minutes) \\
\cline { 3 - 5 } & Liquidambar styraciflua & 14.15 .00 & 14.22 .40 & 7.40 \\
2 & Magnolia grandiflora & 13.35 .40 & 13.46 .50 & 11.10 \\
3 & Liriodendron tulipifera & 14.28 .40 & 14.40 .40 & 12.00 \\
\hline
\end{tabular}

Table 4. Continue.

\begin{tabular}{|c|c|c|c|c|c|c|c|}
\hline \multirow{3}{*}{ № } & \multirow{3}{*}{ Species } & \multicolumn{3}{|c|}{ First decade of August } & \multicolumn{3}{|c|}{ First decade of October } \\
\hline & & \multicolumn{2}{|c|}{ Exposition time } & \multirow{2}{*}{$\begin{array}{l}\text { Necessary time to kill } \\
\text { infusories (in minutes) }\end{array}$} & \multicolumn{2}{|c|}{ Exposition time } & \multirow{2}{*}{$\begin{array}{l}\text { Necessary time to kill } \\
\text { infusories (in minutes) }\end{array}$} \\
\hline & & start & end & & start & end & \\
\hline 1 & Liquidambar styraciflua & 13.45 .00 & 13.51 .30 & 6.30 & 13.50 .10 & 13.58 .55 & 8.45 \\
\hline 2 & Magnolia grandiflora & 14.24 .20 & 14.33 .50 & 9.30 & 14.05 .10 & 14.16 .25 & 11.15 \\
\hline 3 & Liriodendron tulipifera & 14.10 .15 & 14.21 .30 & 11.15 & 13.40 .15 & 13.53 .20 & 13.05 \\
\hline
\end{tabular}

The studied species can be divided in accordance with the strength of phytoncide activity as follows: the species of the strong phytoncide activity - Liquidambar styraciflua; quite strong - Magnolia grandiflora; the species of the medium phytoncide activity - Liriodendron tulipifera.

In the case of our experiment the simple organisms not only hamper their development but are completely destroyed. For a certain period after the destruction all the organelles of their cells are distinctly shown and later their lysis takes place.

For the purpose of comparison, we have included in the experiment plant species known as universal antiseptics [15, 16]: onion (Allium cepa), garlic (Allium sativum), myrthe (Myrtus communis), and geranium (Pelargonium roseum) (table 5). We have determined their protistocide activities in the given situation. As a result, we have found out that protistocide activities of liquidambars approximate to the protistocide activities of onions and cherry-laurel in this experiment.

Table 5. Activity of plants known with strong antiseptic properties in the given experiment.

\begin{tabular}{lll}
\hline № & Species & $\begin{array}{l}\text { Necessary time to kill } \\
\text { infusories (in minutes) }\end{array}$ \\
\hline 4 & Allium cepa L. - onion & 5.35 \\
5 & Allium sativum L. - garlic & 7.05 \\
6 & Myrtus communis 1. - myrtle & 11.05 \\
7 & Pelargonium roseum Ait. - geranium & 9.00 \\
\hline
\end{tabular}

\section{Conclusion}

On the basis of the obtained results we can conclude that North American exotics Liquidambar styraciflua L., Liriodendron tulipifera L., Magnolia grandiflora L. are characterized by complete adaptation to the local humid subtropical climatic conditions along the transcaucasian Black Sea littoral, namely, in Western Georgia, Adjara or South Kolkheti (Colchis). They grow well, develop, give flowers and fruits abundantly, propagate and undergo self-rehabilitation - develop self-seeding forms (except Magnolia) and vegetative shoot forms (except liquidambars).
They are characterized by high antimicrobial action on the basis of protistocidal activity of volatile phytogenic compounds extracted from the leaves. They represent highly-decorative garden-park species in terms of using in decorative gardening and city landscape gardening as well as important forest and woody culture, especially in case of liriodendron; also, they are noteworthy plants for medicine and perfumery.

Finally, on the basis of scientists' recommendations these widely spread species along the Georgian Black Sea littoral can easily be included in the gold fund of decorative gardening and become symbols of exotic flora of the Georgian coastline. Magnolia is characterized by low branch rooting and new specimen's growth only in Batumi, like its habitat. Nomenclature

\section{References}

[1] Pilipenko F. (1978) „Invasive Trees and Shrubs along the Caucasian Black Sea Littoral". "Nauka" Publishing, Leningrad.

[2] Hinkul C. G. (1936) Plant Introduction and Naturalization in Humid Subtropics of the USSR, Batumi Botanical Garden Bulletin. №1, Batumi Subtropical Botanical Garden Publishing, $3-44$.

[3] Manjavidze D., Tsitsvidze A., Matinyan A. (1965) Perspective Varieties of Woody Plants Introduced at Batumi Botanical Garden for Forestry and Forest Management, Tbilisi, "Metsniereba" publishing, $67 \mathrm{p}$.

[4] Kolakovskiy A. (1961) «Vegetative World in Colchis", MSU publishing, Moscow, $459 \mathrm{p}$.

[5] Shetekauri Sh. (1988) Biotops of Petrophytic Flora of the High Mountains Caucasus, Bull. Georgian Academy of Sciences, 159: 3 .

[6] Trees and Shrubs at Batumi Botanical Garden (2007) Part II (The Angiosperms). Editor in Chief - Vano Papunidze. Batumi, $425 \mathrm{p}$.

[7] Trees and shrubs of Batumi Botanical Garden (2012) "Sachino" publishing, Tbilisi. 
[8] Sharashidze Sh., Bagratishvili N. (1988) Batumi Botanical Garden of the Georgian Academy of Sciences, "Adjaria" publishing, Batumi, $179 \mathrm{p}$.

[9] Papunidze V., Bagratishvili N. (1998) "Batumi Botanical Garden of the Georgian Academy of Sciences", "Metsniereba" publishing, Batumi, $155 \mathrm{p}$.

[10] Batumi Botanical Garden - 100 (2102) Published by „SACHINO” Ltd. Tbilisi, 239 p.

[11] Adjaria (1978) "Sabchota Adjara" Publishing 177: 3-46

[12] Rehder Arnold (1949) "Manual or cultivated trees and shrubs". The Macmillan Company, New York, 670 p.

[13] Takhtajyan A. (1978) Floristic Regions of the Earth, Leningrad, "Nauka" 349: 51-91

[14] Flora of North America. Vol. 3 www.erloras.org

[15] Tokin B. (1960) Microbe Destroyers, Phytoncides. Moscow, "Nauka" publishing, $160 \mathrm{p}$.

[16] Tokin B. (1975) On the Role of Phytoncides in Nature. Collection "Phytoncides, their Role in Nature", Leningrad University Publishing, 235: 5-21.

[17] Beideman I. (1974) "Methodology of the Study of Plants and Plant Communities Phenology", "Nauka" publishing, Novosibirsk

[18] Elagin, I., Lobanov A. (1979). "Atlas Guide of Plant Phenological Phases", "Nauka" publishing, Moscow, 95 p.
[19] Gocholashvili M., Zaldastanishvili Sh., Demetradze T. (1959), "Frost and Winter Resistance of Woody Subtropical Flower Varieties" (journal "Subtropical Cultures”, №1, pp. 3-12.

[20] Methodological Guidebook for Plant Reproduction, Developed by Principal Botanic Garden (1974). Nauka" publishing, Moscow, $125 \mathrm{p}$.

[21] Khromova T. (1980) "Methodological Guidebook for Reproduction of Introduced Woody Plants with Grafts". ВАСХНИЛ" publishing. Moscow 140 p.

[22] An Update of the Angiosperm Phylogeny Group Classification for the Orders and Families of Flowering Plants: APG II (2003) Botanical journal of the Linnean Society, 141: 399-436.

[23] V. Kholyavko, Globa-Mikhaylenko D. (1976) "Valuable Woody Varieties along the Black Sea Littoral", "Lesnaya Promishlennost" publishing, $340 \mathrm{p}$.

[24] www.IUCNredlist.org

[25] http://www.cbd.int/doc/publications/plant-conservation-report -en.pdf

[26] Nevton A., Oldfield S., Fragoso G., Paul M., Miles L., Edwards M. (2003) "Towards a Global Tree Conservation Atlas. Mapping the status and distribution of the world's threatened tree species", World Conservation Monitoring Centre, Cambridge, United Kingdom.

[27] Tskhoidze T., Tchaidze F., Kontselidze N., Jakeli J. (2014) Bioecology of tulip Trees at the Adjara Black Sea Coast. „, Modern Phytomorphology." Vol. 6, Lvov, pp.189-194. www. phytomorphology.org 